\title{
Raf/KSR/Mek1 Trimer
}

National Cancer Institute

\section{Source}

National Cancer Institute. Raf/KSR/Mek1 Trimer. NCI Thesaurus. Code C156755.

An indication that trimeric protein complexes containing a RAF family protein, a kinase suppressor of Ras (KSR) family protein and MAP2K1 have been detected after subjecting a sample to a proximity ligation assay. 